\title{
Deficiency in Phosphorylase Phosphatase Activity despite Elevated Protein Phosphatase Type-1 Catalytic Subunit in Skeletal Muscle from Insulin-resistant Subjects
}

\author{
Bulangu L. Nyomba, David L. Brautigan, ${ }^{*}$ Keith K. Schlender, ${ }^{\ddagger}$ Wei Wang, ${ }^{\ddagger}$ Clifton Bogardus, and David M. Mott \\ Clinical Diabetes and Nutrition Section, National Institute of Diabetes and Digestive and Kidney Diseases, National Institutes of Health, \\ Phoenix, Arizona 85016; *Brown University, Division of Biology and Medicine, Providence, Rhode Island 02912, \\ and ${ }^{\ddagger}$ Medical College of Ohio, Department of Pharmacology, Toledo, Ohio 43699
}

\begin{abstract}
Glycogen synthase is activated by protein phosphatase type-1 (PP-1). The spontaneous PP-1 activity accounts for only a small fraction of total PP-1 activity, which can be exposed by trypsin digestion of inhibitor proteins in the presence of $\mathrm{Mn}^{2+}$. We determined total PP-1 activity in muscle biopsies from insulin-sensitive and -resistant nondiabetic Pima Indians. Inhibitor-2 sensitive PP-1 represented $90 \%$ of total phosphatase activity. Spontaneous and total PP-1 activities were reduced in insulin resistant subjects $(P<0.05-0.01)$, suggesting that the reduced PP-1 activity is not the result of inhibition by trypsinlabile phosphatase regulatory subunits. This difference was further investigated by Western blots using two different antibodies. An antibody raised against the rabbit muscle PP-1 catalytic subunit was used to analyze muscle extracts concentrated by DEAE-Sepharose adsorption. An antibody raised against a peptide derived from the COOH-terminal end of the PP-1 catalytic subunit was used to analyze crude muscle extracts. Both antibodies recognized a PP-1 catalytic subunit of $\sim 33 \mathrm{kD}$, which unexpectedly was more abundant in insulin-resistant subjects $(P<0.05-0.01)$. The increase in the tissue PP-1 protein content may be a response to compensate for the impairment in the enzyme activity. ( $J$. Clin. Invest. 1991. 88:15401545.) Key words: glycogen synthesis $\bullet$ inhibitor- $2 \cdot$ insulin action • protein phosphorylation • Pima Indians
\end{abstract}

\section{Introduction}

We have previously shown a close relationship between in vivo insulin-mediated glucose disposal rate and insulin-stimulated glycogen synthase activity of skeletal muscle in man and suggested that a defect in the regulation of this enzyme by insulin may contribute to insulin resistance in Pima Indians (1). Although the mechanisms for insulin regulation of glycogen synthase are not fully understood, changes in the phosphorylation state of this enzyme alter its activity $(2,3)$ and it has been

Parts of this work appeared in abstract form (1990. Diabetes. 39(Suppl. 1):13a).

Address correspondence to Dr. David M. Mott, Clinical Diabetes and Nutrition Section, National Institute of Diabetes and Digestive and Kidney Diseases, National Institutes of Health, 4212 N. 16th St., Rm. 541, Phoenix, AZ 85016. 1991.

Received for publication 25 March 1991 and in revised form 20 June

J. Clin. Invest.

(C) The American Society for Clinical Investigation, Inc.

$0021-9738 / 91 / 11 / 1540 / 06 \$ 2.00$

Volume 88, November 1991, 1540-1545 proposed that activation of this enzyme by insulin may be achieved through inhibition of protein kinases known to phosphorylate glycogen synthase or by stimulation of protein phosphatases, which dephosphorylate this enzyme (2-6).

Alemany et al. (7) have suggested that in vivo dephosphorylation of both glycogen synthase and phosphorylase are primariły catalyzed by the catalytic subunit of protein phosphatase type-1 (PP-1). ${ }^{1}$ This enzyme has both active and inactive forms bound to targeting regulatory subunits distributed in different cell compartments (8-10). Skeletal muscle glycogen synthase phosphatase activity is reduced in insulin-resistant subjects, both fasting $(11,12)$ and during in vivo insulin stimulation (12), but it is not known whether this is due to an abnormality in the catalytic subunit of PP-1 or due to inhibition by regulatory subunits. The present study was undertaken to investigate whether the total activity of PP-1 (independent of inhibitor proteins) is impaired and if the total enzyme protein content is deficient in insulin-resistant man. The results show a reduction in total PP-1 activity, but an increase in the immunoreactive PP-1 catalytic subunit in association with insulin resistance.

\section{Methods}

Subjects. 12 Pima Indians were studied. They gave informed consent, and the studies were approved by the ethics committees of the National Institutes of Health, the Indian Health Service, and the Gila River Indian Community, where the subjects were living. Fitness for the study was determined by medical history, physical examination, electrocardiography, and routine biochemical, hematological, and urine testing. None of the subjects was taking any medication and no subject had any abnormalities on these examinations. They were studied at the Clinical Diabetes and Nutrition Section of the National Institutes of Health, Phoenix, AZ, after being stabilized for $\sim 7 \mathrm{~d}$ on a weight-maintaining diet (20\% protein, $50 \%$ carbohydrate, and $30 \%$ fat). Body fat was determined by underwater weighing, with simultaneous determination of residual lung volume, and fat-free mass (FFM) was calculated. Diabetes was excluded after an oral glucose tolerance test using World Health Organization Criteria.

Subjects were further characterized by their glucose disposal rate during a euglycemic clamp, performed as previously described in detail (13). In brief, the plasma insulin concentration was raised by means of a primed continuous infusion of insulin, and glucose was infused to maintain the plasma glucose at the basal level. The rate of glucose uptake is a measure of insulin action. Two infusions of insulin (Velosulin; Nordisk, Bethesda, MD) were given consecutively, each lasting 100 $\min : 40 \mathrm{mU} / \mathrm{m}^{2} \cdot \min$ (low dose) and $400 \mathrm{mU} / \mathrm{m}^{2} \cdot \min$ (high dose), resulting in steady-state plasma insulin concentrations of $132 \pm 12 \mathrm{mU} /$ liter and $2442 \pm 161 \mathrm{mU} /$ liter. Before and during the infusion of the low dose of insulin, tracer amounts of $\left[3-{ }^{3} \mathrm{H}\right]$ glucose were infused to mea-

1. Abbreviations used in this paper: FFM, fat-free mass; G-subunit, glycogen-binding subunit of PP-1; PP-1, protein phosphatase type-1. 
sure the rate of appearance of glucose. Endogenous glucose production was calculated by subtracting the rate of exogenous glucose infusion from the total rate of appearance of glucose calculated using Steele's non-steady state equations (14). The total glucose disposal rate at low insulin dose is equal to the total rate of glucose appearance. Subjects were arbitrarily considered insulin resistant if their glucose disposal rates at the low and high doses of insulin were $<3$ and $9 \mathrm{mg} / \mathrm{kg}$ FFM per min, respectively, whereas they were considered insulin sensitive if their glucose disposal rates were higher. The characteristics of the subjects are shown in Table I.

Muscle extracts. After an overnight fast, percutaneous muscle biopsies were taken from the quadriceps femoris muscle after local anesthesia of skin and fascia with xylocaine. Specimens $(\sim 300 \mathrm{mg})$ were collected within 5 min using the Bergstrom needle (Depuy, Phoenix, AZ), and were frozen in liquid nitrogen within $15 \mathrm{~s}$, lyophilized, and powdered (12). Muscle powder was stored at $-70^{\circ} \mathrm{C}$ until assayed. Frozen muscle powder was homogenized using an Omni homogenizer (Omni International, Waterbury, $C T$ ) in $15 \mu \mathrm{l} / \mathrm{mg}$ powder of an ice-cold 20 mM Mops buffer, pH 7.5, containing 5 mM EDTA, 0.5 mM EGTA, 5 $\mathrm{mM} \mathrm{NaN}_{3}, 1 \mathrm{mM}$ DTT, and $0.15 \mathrm{mM}$ or $0.3 \mathrm{mM}$ of freshly added PMSF (buffer A). The homogenates were centrifuged at $10,000 \mathrm{~g}$ for 20 min at $4^{\circ} \mathrm{C}$ in a Sorvall centrifuge. The resulting supernatant was used for the assay of phosphorylase phosphatase. Alternatively, homogenization was performed in $30 \mu \mathrm{l} / \mathrm{mg}$ powder of $20 \mathrm{mM}$ Mops buffer, $\mathrm{pH}$ 7.5 , containing $10 \mathrm{mM}$ EDTA, $10 \mathrm{mM}$ EGTA, $10 \mathrm{mM}$ benzamidine, $0.3 \% \beta$-mercaptoethanol, $5 \mu \mathrm{g} / \mathrm{ml}$ leupeptin, $1 \mu \mathrm{g} / \mathrm{ml}$ pepstatin, $1 \mathrm{mM}$ DTT, and $0.1 \mathrm{mM}$ of freshly added PMSF (buffer B). After centrifugation, the supernatant was used for immunological detection of PP-1.

Phosphorylase phosphatase assay. Phosphorylase phosphatase activity was assayed by the release of ${ }^{32} \mathrm{P}$ from [ $\left.{ }^{32} \mathrm{P}\right]$-phosphorylase $a$ as described by Nimmo and Cohen (15). Rabbit muscle phosphorylase $b$ (P-6635; Sigma Chemical Co., St. Louis, MO) was phosphorylated with phosphorylase kinase (P-2014, Sigma Chemical Co.) and [gamma- ${ }^{32} \mathrm{P}$ ]ATP (sp act $50-80 \mathrm{cpm} / \mathrm{pmol}$; New England Nuclear, Boston, MA) as described by Antoniw et al. (16). Muscle extracts and [ $\left.{ }^{32} \mathrm{P}\right]$-phosphorylase $a(2 \mathrm{mg} / \mathrm{ml})$ were mixed in a total volume of $70 \mu l$ and the mixture was incubated at $30^{\circ} \mathrm{C}$ for $5 \mathrm{~min}$. The reaction was terminated by adding $100 \mu \mathrm{l}$ of ice-cold $17.5 \%$ TCA and $100 \mu \mathrm{l}$ of $6 \mathrm{mg} / \mathrm{ml} \mathrm{BSA}$. Denatured protein was removed by centrifugation at $10,000 \mathrm{~g}$ for 4 $\min$ at $4^{\circ} \mathrm{C}$, and the amount of radioactivity was determined in $200 \mu \mathrm{l}$ of the supernatant. The radioactivity in the absence of muscle extract (nonspecific dephosphorylation of phosphorylase $a$ ) was subtracted from the activity in the presence of muscle extract. Phosphatase activity was expressed as nanomoles ${ }^{32} \mathrm{P}$ hydrolyzed per gram dry weight muscle per minute (nanomoles ${ }^{32} \mathrm{P} / \mathrm{g} \cdot \mathrm{min}$ ). As assayed, the enzyme activity reflects the spontaneous, physiologic phosphatase activity. PP1 has been found in active or inactive conformations $(9,10,17)$, in association with heat-stable inhibitors or anchored to glycogen, microsomes, and myofibrils by targeting proteins (8). These heat-stable inhibitors and targeting proteins may be destroyed by mild proteolysis to expose the latent enzyme activity. Inactive PP-1 can be activated by

Table I. Subjects Characteristics

\begin{tabular}{lcc}
\hline & Insulin sensitive & Insulin resistant \\
\hline Number & 7 & 5 \\
Age $(y r)$ & $26 \pm 4$ & $31 \pm 3^{*}$ \\
Percent fat & $25 \pm 12$ & $37 \pm 7$ \\
Fasting glucose $(\mathrm{mg} / \mathrm{dl})$ & $87 \pm 5$ & $91 \pm 6$ \\
Fasting insulin $(\mathrm{mU} / \mathrm{liter})$ & $19 \pm 2$ & $54 \pm 1^{\ddagger}$ \\
Low dose M $(\mathrm{mg} / \mathrm{kg} \mathrm{FFM} / \mathrm{min})$ & $4.8 \pm 0.5$ & $2.4 \pm 0.2^{\ddagger}$ \\
High dose $\mathrm{M}(\mathrm{mg} / \mathrm{kg} \mathrm{FFM} / \mathrm{min})$ & $13.1 \pm 0.9$ & $7.3 \pm 0.5^{\S}$
\end{tabular}

Data shown as the mean \pm SD. ${ }^{*} P<0.05$ vs. sensitive. ${ }^{\ddagger} P<0.01$ vs. sensitive. ${ }^{5} P<0.001$ vs. sensitive. $M$, glucose disposal rate during euglycemic clamp. divalent cations $\mathrm{Co}^{2+}$ and $\mathrm{Mn}^{2+}(9,10,18)$. To detect total PP-1 activity, therefore, muscle extracts were incubated for $5 \mathrm{~min}$ with $1 \mathrm{mM}$ $\mathrm{Mn}^{2+}$ and $50 \mu \mathrm{g} / \mathrm{ml}$ TPCK-trypsin (Sigma Chemical Co.) in a total volume of $40 \mu \mathrm{l}(9,10,18)$. Trypsin digestion was stopped by adding 60 $\mu \mathrm{l}$ of ice-cold Mops buffer containing sixfold concentration of Limabean trypsin inhibitor. Control samples without $\mathrm{Mn}^{2+}$ or trypsin were similarly diluted. $50 \mathrm{ml}$ of this mixture were used in the phosphatase assay as described above. Because of these manipulations, the final assay contained a 14-fold dilution of the original muscle extract. To confirm that the enzyme activated by trypsin/ $\mathrm{Mn}^{2+}$ was PP-1, trypsintreated extracts were incubated for $15 \mathrm{~min}$ with $30 \mathrm{ng}$ of a rabbit muscle inhibitor-2 (a generous gift from Dr. J. Vandenheede, University of Leuven, Belgium) before initiating the reactions with $\left[{ }^{32} \mathrm{P}\right]$-phosphorylase.

$D E A E$-Sepharose adsorption. PP-1 in muscle extracts was concentrated at $4^{\circ} \mathrm{C}$ by adsorption of $100 \mu \mathrm{l}$ muscle extract in buffer $A$ on a 0.3 $\mathrm{ml}$ DEAE-Sepharose CL-6B microcolumn. After washing the column with 20-column volumes of buffer $A$ containing $0.05 \mathrm{M} \mathrm{NaCl}$, protein phosphatase was eluted with buffer A containing $0.5 \mathrm{M} \mathrm{NaCl}$.

Western blotting. Immunoblotting of DEAE-Sepharose eluates was performed as previously described $(19,20)$. Briefly, eluates were boiled in Laemmli sample buffer for $5 \mathrm{~min}$ and the mixtures were resolved by SDS/10\% PAGE in slab gels. Molecular weights were estimated using prestained molecular weight standards (Bio-Rad Laboratories, Inc., Richmond, CA) which had been recalibrated with Bio-Rad's unstained standards. Proteins were electrically transferred from the gels onto nitrocellulose membranes using a Bio-Rad apparatus at $30 \mathrm{~V}$ overnight followed by $60 \mathrm{~V}$ for $60 \mathrm{~min}$. After protein transfer, the nitrocellulose was blocked for $60 \mathrm{~min}$ with a quench solution $(10 \mathrm{mM}$ Tris- $\mathrm{HCl}, 150$ $\mathrm{mM} \mathrm{NaCl}, 5 \% \mathrm{BSA}, \mathrm{pH}$ 7.4). The nitrocellulose was incubated overnight at room temperature with specific, affinity-purified sheep antiPP-1 catalytic subunit IgGs $(19,20)$. The bound IgGs were reacted for 2 $h$ at room temperature with rabbit anti-sheep IgGs which in turn were detected after ${ }^{125} \mathrm{I}$-protein $\mathrm{A}$ binding for $60 \mathrm{~min}$. The nitrocellulose was used to expose Kodak X-omat $\mathrm{AR}$ x-ray film at $-70^{\circ} \mathrm{C}$ with a DuPont Cronex intensifying screen (Eastman Kodak Co., Rochester, NY). Autoradiographic bands were quantified by densitometry using the BioRad video densitometer or the model GS300 scanning densitometer (Hoefer Scientific Instruments, San Francisco, CA) connected to a model 3390A integrator (Hewlett-Packard Co., Avondale, PA).

Crude muscle extracts in buffer B were submitted to SDS/PAGE and Western immunoblotting as described above with the following exceptions. The first antibody was prepared against a peptide (Cys-ThrPro-Pro-Arg-Asn-Ser-Ala-Lys-Ala-Lys-Lys) corresponding to the $\mathrm{COOH}$-terminus of PP-1 catalytic subunit. The peptide was coupled to the carrier protein keyhole limpet hemocyanin through the cysteine residue added to the $\mathrm{NH}_{2}$-terminus, the antibodies were raised against the coupled peptide in rabbits and immunopurified using the peptide covalently bound to Immobilon AV membrane (Millipore Corp., Bedford, MA). The purified antibody was specific for PP-1 catalytic subunit (21). The IgGs were detected by ${ }^{125}$ I-protein A binding. After autoradiography, the immunoreactive bands were cut out and the incorporated radioactivity was determined in a gamma-counter.

Other assays. Protein content of muscle extracts was determined by the Bio-Rad protein dye assay. Plasma glucose concentration was measured by the glucose oxidase method using a glucose analyzer (Beckman Instruments, Inc., Fullerton, CA). Plasma insulin concentrations were determined by RIA (22).

Statistical analyses. Analyses were performed using Statistical Analysis System Institute computer software (Cary, NC). The unpaired, two-tailed $t$-test was used to calculate the statistical significance of the differences. Data are presented as means \pm SEM, unless otherwise indicated.

\section{Results}

Phosphorylase phosphatase activity. Phosphatase activity in muscle extracts from experimental groups was determined at 
the same time as in a muscle powder pool from four different subjects, used as a standard. The coefficient of variation of this pooled sample was $16 \%$ for the assay of spontaneous phosphatase activity and $12 \%$ for total (post-trypsin/ $\mathrm{Mn}^{2+}$ ) phosphatase activity (Table II). Muscle protein content was similar between resistant $(310 \pm 20 \mathrm{mg} / \mathrm{g}$ dry $\mathrm{wt})$ and sensitive $(347 \pm 40 \mathrm{mg} / \mathrm{d}$ dry wt) subjects. The intergroup differences in phosphatase activities were determined in two sets of experiments. In both experiments, spontaneous and total activities were significantly reduced in insulin-resistant subjects (Table III).

To study the contribution of PP-1 to the observed activity, trypsin/ $\mathrm{Mn}^{2+}$-treated extracts were incubated with inhibitor-2. Under these conditions, which define PP-1, phosphatase activity was inhibited by $\sim 90 \%$ (Tables II and III $A$ ). The remaining activity, which is an estimate of phosphatase $2 \mathrm{~A}$ activity, was not different among the groups. The individual effects of $\mathrm{Mn}^{2+}$ and trypsin were also studied (Table III $B$ ). $\mathrm{Mn}^{2+}$ alone increased phosphatase activity by $\sim 40 \%$ in insulin-sensitive and by $\sim 60 \%$ in -resistant subjects to give about the same level of activity in the two groups. An approximate threefold increase in phosphatase activity was observed in both groups in the presence of trypsin alone. When $\mathrm{Mn}^{2+}$ and trypsin were combined, the highest level of phosphatase activity (total) was obtained, with an increase of 4.5-fold in sensitive and of 4.9fold in resistant subjects, compared to the spontaneous activity. Like spontaneous and total phosphatase activities, posttrypsin activity was significantly lower in insulin-resistant than in sensitive subjects (Table III $B$ ).

Western immunoblotting of protein phosphatase type-1. We investigated whether the reduced activity of phosphatase in insulin-resistant subjects is due to a reduced content of PP-1 catalytic subunit. Muscle extracts were immunoblotted with a sheep antibody developed against the rabbit muscle PP-1 catalytic fragment $(19,20)$. This antibody requires $100-500 \mathrm{ng}$ PP1 for detection and did expose a $\sim 33-\mathrm{kD}$ band in crude muscle extracts analyzed by Western blotting. However, the intensity of staining was weak and not readily detected over a range of dilutions. Therefore, instead of crude tissue extracts, DEAESepharose concentrates of muscle extracts were used in Western blotting, exposing the major band of $\sim 33 \mathrm{kD}$ (see Fig. 1). The antibody also recognized a band of $\sim 70 \mathrm{kD}$ and two faint bands of $\sim 37$ and $\sim 45 \mathrm{kD}$ but these were not consistently present in all the samples and were therefore excluded from comparative studies. In two preliminary experiments, PP-1 im-

Table II. Effects of Trypsin/ $/ \mathrm{Mn}^{2+}$ and Inhibitor-2 on Phosphorylase Phosphatase Activity of a Muscle Pool Used as Internal Standard

\begin{tabular}{|c|c|c|c|}
\hline Condition & No. assays & Activity & \% C.V. \\
\hline No addition & 9 & $20 \pm 1$ & 16 \\
\hline Trypsin/ $\mathbf{M n}^{2+}$ & 10 & $78 \pm 3$ & 12 \\
\hline Trypsin/ $\mathbf{M n}^{2+} /$ inhibitor- 2 & 7 & $7 \pm 1$ & 11 \\
\hline
\end{tabular}

Muscle powder from four different subjects was pooled and mixed together. An aliquot of this powder was homogenized in buffer A (see Methods) containing $0.3 \mathrm{mM}$ PMSF and used as an internal standard every time patient samples were assayed. Activity is expressed in nanomoles per grams - minutes and shown as the mean \pm SEM.
Table III. Phosphorylase Phosphatase Activity in Insulin-sensitive and-Resistant Subjects

\begin{tabular}{lrc}
\hline & Sensitive & Resistant \\
\hline A. Experiment I & & \\
Spontaneous & $25 \pm 2(7)$ & $20 \pm 2(5)^{*}$ \\
Posttrypsin/Mn' & & \\
Posttrypsin/ $/ \mathrm{Mn}^{2+} /$ inhibitor-2 & $83 \pm 3(7)$ & $60 \pm 4(5)^{\ddagger}$ \\
B. Experiment II & $8 \pm 1(7)$ & $6 \pm 1(3)$ \\
Spontaneous & & \\
Post-Mn & & \\
Posttrypsin & $23 \pm 1(6)$ & $19 \pm 1(4)^{*}$ \\
Posttrypsin/Mn & $32 \pm 2(6)$ & $30 \pm 3(4)$ \\
& $77 \pm 1(6)$ & $61 \pm 1(4)^{8}$ \\
& $104 \pm 1(6)$ & $93 \pm 3(4)^{*}$ \\
\end{tabular}

Muscle tissues were homogenized in buffer A (see Methods) containing $0.3 \mathrm{mM}$ (Experiment I) or $0.15 \mathrm{mM}$ (Experiment II) of freshly added PMSF. Activity is expressed in nanomoles per grams - minute. Data shown as the mean \pm SEM, and the number of subjects is shown in parentheses. ${ }^{*} P<0.05$ vs. sensitive. ${ }^{\ddagger} P<0.01$ vs. sensitive. ${ }^{8} P$ $<0.001$ vs. sensitive.

munoreactivity in the $\sim 33-\mathrm{kD}$ band, expressed as OD (area) per nanogram total protein, was $\sim 1.5$ times higher in an insulin-resistant subject compared to a sensitive control, i.e., 295 vs. 206 , and 173 vs. 116 , respectively. Fig. 1 is an autoradiogram of a series of diluted samples comparing an insulin-resistant and an insulin-sensitive subject, showing increased PP-1 immunoreactivity in the resistant subject.

To quantify PP-1 immunoreactivity, four serial dilutions of rabbit muscle PP-1 used as a standard were analyzed in each experiment in parallel with four dilutions of muscle DEAE extracts from one sensitive and one resistant subject. For every subject a PP-1 concentration index was calculated as the ratio of the slope of the OD vs. sample protein for this subject to the slope of the O.D. vs. protein for the rabbit PP-1 (defined as 100). As shown in Table IV, this index was significantly higher in resistant than in sensitive subjects, showing a net increase in PP-1 as a function of the muscle extract protein.

In another series of experiments, unfractionated muscle extracts were reacted with a rabbit antibody raised against a syn-

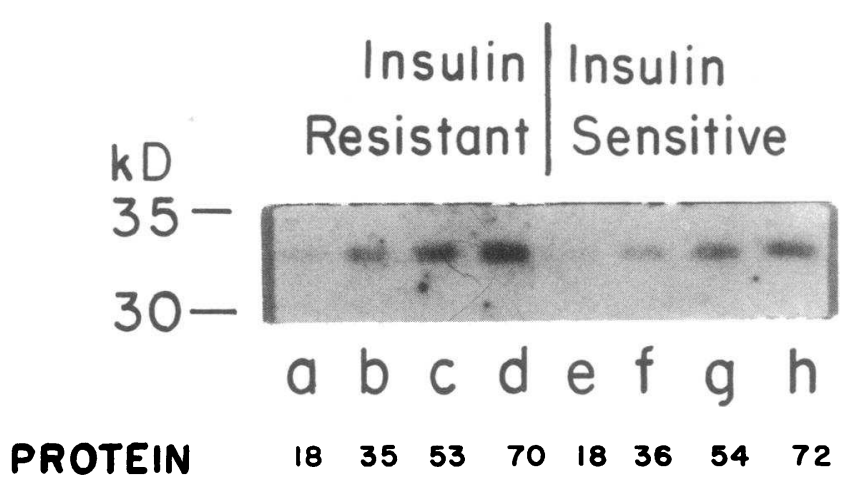

Figure 1. Autoradiograph of PP-1 in muscle DEAE concentrates. Identical dilutions of muscle extracts from one insulin resistant $(a-d)$, and one insulin sensitive subject $(e-h)$ were used for electrophoresis and electroblotting onto nitrocellulose. Affinity purified IgGs against rabbit skeletal muscle $33 \mathrm{kD}$ catalytic subunit of PP-1 were used to detect the PP-1 catalytic subunit as described in Methods. The amount of protein loaded per lane is shown. 
Table IV. Quantitation of Immunoreactive Protein Phosphatase Type-1 in Insulin-sensitive and -Resistant Subjects

\begin{tabular}{lcc}
\hline & Sensitive & Resistant \\
\hline $\begin{array}{c}\text { Anti-PP-1 antibody } \\
\text { (DEAE concentrate, Index) }\end{array}$ & $78 \pm 8(6)$ & $138 \pm 15(4)^{*}$ \\
$\begin{array}{c}\text { Anti-peptide antibody } \\
\text { (Crude extract, cpm) }\end{array}$ & $3615 \pm 266(4)$ & $4561 \pm 233(3)^{\ddagger}$ \\
\hline
\end{tabular}

Anti-PP-1 antibody: Muscle extracts concentrated by DEAE-Sepharose adsorption were diluted as described in the text, immunostained with a sheep antibody against rabbit muscle PP-1 catalytic fragment. After ${ }^{125}$ I-protein A binding and autoradiography, the $33-\mathrm{kD}$ peptide was quantitated by densitometry. A PP-1 concentration index was calculated for every subject as the ratio of the slope of the OD vs. protein for this subject to the slope of the OD vs. protein for the rabbit PP-1 used as a standard (defined as 100). This PP-1 concentration index (mean \pm SEM) is shown, and the number of subjects is shown in parentheses. Anti-peptide antibody. Crude muscle extracts were immunostained with a rabbit antibody against a synthetic peptide derived from the $\mathrm{COOH}$-terminal end of the PP-1 catalytic subunit. PP-1 was quantitated by ${ }^{125}$ I-protein A assay as described in Methods. The autoradiograph corresponding to these data is illustrated in Fig. 2. Data are shown as mean counts per minute bound ( \pm SEM), and the number of subjects is shown in parentheses. ${ }^{*} P<0.01$ vs. sensitive. ${ }^{\ddagger} P<0.05$ vs. sensitive.

thetic peptide representing the $\mathrm{COOH}$-terminal end of the PP1 catalytic subunit. PP-1 was quantitated by ${ }^{125}$ I-protein A assay as described in Methods. This antibody like the anti-PP-1 catalytic fragment, detected a major band of immunoreactivity of $\sim 33 \mathrm{kD}$ (Fig. 2) the intensity of which increased with decreasing in vivo insulin-mediated glucose disposal rate. The immunoreactivity bound to the $33-\mathrm{kD}$ band was significantly higher in the resistant compared to the sensitive subjects (Table IV). Similar results were obtained when the autoradiography bands were quantitated by densitometry (not shown). Other bands were evident at $\sim 45$ and $\sim 37 \mathrm{kD}$. However, there was no difference in the immunoreactivity of the $45-\mathrm{kD}$ band between sensitive $(1,605 \pm 230 \mathrm{cpm}$ bound) and resistant $(1,654 \pm 176 \mathrm{cpm}$ bound) subjects, and the $37 \mathrm{kD}$ was too faint

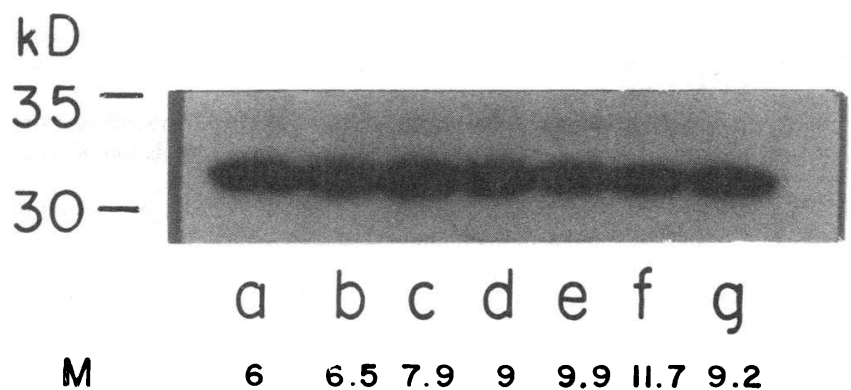

Figure 2. Autoradiograph of PP-1 in crude muscle extracts. Muscle extracts from seven subjects were subjected to electrophoresis and electroblotting, and were immunoblotted using affinity purified IgGs raised against the 10 amino acid $\mathrm{COOH}$-terminal peptide of the rabbit muscle catalytic subunit of PP-1 (see Methods). Quantitation of PP-1 with this anti-peptide antibody is shown in Table IV comparing insulin-sensitive and -resistant subjects. The material loaded per lane was equivalent to $1 \mathrm{mg}$ dry wt muscle. The glucose disposal rates at the high dose of insulin are shown for the different subjects $(a-g)$. to be included in comparative studies. Results with the two anti-PP-1 antibodies used in this study support the conclusion that muscle content of PP-1 catalytic subunit is increased in insulin-resistant subjects.

\section{Discussion}

Basal and insulin-stimulated activities of glycogen synthase phosphatase are reduced in insulin-resistant Pima Indians (11, 12). We have investigated the nature of the defect and found a significantly reduced spontaneous activity of phosphorylase phosphatase and lower total PP-1 activity in insulin-resistant subjects.

Protein phosphatases involved in the regulation of glycogen metabolism have been classified into type-1 and type-2 (5) according to their specificity for the subunits of the substrate phosphorylase kinase and their inhibition by heat stable inhibitor proteins (inhibitor- 1 and inhibitor-2). PP-1 comprises a catalytic subunit bound to targeting subunits such as the G-subunit in glycogen particles and in the microsomes (8). It is now known that PP-1 catalytic subunit exists in an active but inhibited conformation in the microsomes (10), whereas in the cytosol the PP-1 catalytic subunit complexed with inhibitor- 2 may be mostly inactive (23). The catalytic subunit in the glycogen particles is considered to exist only in an active conformation (24). It appears therefore that spontaneous phosphatase activity is mostly PP-1 in glycogen particles, whereas after trypsin digestion phosphatase activity is the result of the release of active PP-1 from glycogen and microsomal particles as well as from inhibitor-2. The PP-1 that is in an inactive conformation may be further activated by $\mathrm{Mn}^{2+}$ or $\mathrm{Co}^{2+}$ treatment, so the combination of any of these divalent cations with trypsin allows the measurement of total PP-1 activity in tissue extracts $(4,10,17,18)$

The decrease in the spontaneous phosphatase activity in insulin-resistant subjects indicates that active PP-1 is reduced in the cytosol, glycogen particles, or both. This activity increased towards normal after $\mathrm{Mn}^{2+}$ treatment, suggesting that the $\mathrm{Mn}^{2+}$ responsive form of PP-1 $(4,25)$ might be abnormally high in insulin-resistant subjects. Whether the PP-1 defect is primary or secondary to hormonal dysregulation is not known.

The hormonal regulation of PP-1 activity is still poorly understood. Heat-stable inhibitors and targeting subunits have been shown to have a regulatory function on PP-1 activity. From studies on experimental diabetes it is not clear whether changes in heat-stable inhibitor activity determine the decreased PP-1 activity associated with insulin deficiency (2628). The G-subunit is thought to be a specific receptor for PP-1 (10) and is a physiological substrate for CAMP-dependent protein kinase. Phosphorylation of the G-subunit in response to adrenaline triggers the release of the catalytic subunit into the cytosol, but this has no apparent direct effect on PP-1 activity (8). Dissociation of the catalytic subunit of PP-1 from glycogen has also been observed in the presence of inhibitor-2 (29). This dissociation of PP-1 from the G-subunit has been proposed as an inactivation mechanism for PP-1, because in animals adrenaline decreases the PP-1 activity associated with glycogen particles (30). Also, in a recent study, insulin stimulated a protein kinase that activated glycogen-bound PP-1 by a mechanism that did not involve dissociation, but rather G-subunit phosphorylation on a specific site, also phosphorylated by cAMPdependent protein kinase in response to adrenaline (31). 
Theoretically, regulatory or targeting proteins could account for the impaired PP-1 activity in insulin-resistant subjects, either by a limited response to insulin or by an excessive response to counterregulatory hormones. The lower activity of PP-1 observed in insulin-resistant subjects is not likely due to regulatory proteins because the abnormality is not corrected by trypsin. Trypsin also removes a $\sim 4-\mathrm{kD}$ peptide $(32,33)$ at the $\mathrm{COOH}$-terminal end of the catalytic subunit, leaving a slightly more active, stable, nicked catalytic subunit. The low total PP1 activity observed in insulin-resistant subjects is not an artifact introduced by trypsin because PP-1 activity was also low before trypsin treatment. The defect resides in the PP-1 catalytic subunit, because inhibitor- 2 removed the activity difference between insulin-sensitive and -resistant subjects. Inhibitor-2-sensitive phosphatase was $\sim 90 \%$ of total phosphatase activity, similar to that reported for the rabbit $(9,34)$, indicating that virtually all the phosphatase activity in human muscle was due to PP-1. Similar results were obtained using okadaic acid to inhibit PP-1 (unpublished observations).

A significant reduction in the total PP-1 activity in insulinresistant subjects could be simply explained by a reduced level of PP-1 catalytic subunit. Antibodies specific for rabbit muscle PP-1 catalytic subunit could be used to determine the content of human muscle PP-1 catalytic subunit because the amino acid sequence of PP-1 catalytic subunit is highly conserved (35), and has been predicted by gene sequence analysis to be identical in humans and the rabbit (36). We first used an antibody raised against the PP- 1 catalytic fragment on muscle extracts concentrated by ion-exchange adsorption $(19,20)$, and found a major $\sim 33-\mathrm{kD}$ immunoreactive PP-1 catalytic subunit. The concentration of this catalytic subunit was higher in insulin-resistant subjects. A second antibody raised against the 11 amino acid COOH-terminal end of the PP-1 catalytic subunit, was used on crude muscle extracts. The results were similar with both antibodies, showing that insulin-resistant subjects have more PP-1 catalytic subunit in their muscle extracts. These results indicate that the reason for the impairment of phosphatase activity in insulin-resistant subjects is not simply a reduced level of the PP-1 catalytic subunit.

The reported molecular mass of unproteolyzed rabbit muscle PP- 1 catalytic subunit determined by SDS-PAGE is $\approx 37$ $\mathrm{kD}(8)$. In the absence of protease inhibitors PP-1 catalytic subunit can be converted to a 33-kD species by removal of $\sim 30$ amino acid residues from the $\mathrm{COOH}$-terminus $(32,33)$ and this species does not react with the antipeptide antibody (Wang, W., and K. K. Schlender, unpublished observation). Both 33- and 37-kD species were detected in the human muscle extracts. The fact that the $33-\mathrm{kD}$ species in the human skeletal muscle extracts reacts with the antipeptide antibody suggests that this catalytic subunit is not a proteolytic fragment of the $37-\mathrm{kD}$ subunit. It is likely that the $33-\mathrm{kD}$ species in human muscle is a low-molecular weight isoform of the PP-1 catalytic subunit. Examples of such isoforms of PP-1 catalytic subunit have been recently published for different species $(8,37,38)$.

This is the first time an immunologic determination of PP1 or enzymatic determination of total PP-1 activity has been performed in a study of human insulin resistance. There was a dissociation between PP-1 protein level and total enzymatic activity in these subjects. A similar dissociation was recently reported by Gruppuso and Brautigan (39) who found that immunoreactive PP-1 in fetal rat liver had a reduced response to metabolic and hormonal changes.
It is not known at this time whether the PP-1 defect is due to genetic or posttranslational alterations in the catalytic subunit, and there is no evidence for direct covalent regulation of this subunit by insulin. The only documented posttranslational modification of this subunit is its phosphorylation on tyrosine by the oncogene product pp $60^{\mathrm{v}-\mathrm{src}}$, which abolishes the enzyme activity (40).

The complex regulation of glycogen synthase involves activation by PP-1 and inhibition by various kinases as previously discussed (41). We have recently reported an increased cAMPdependent protein kinase activity in insulin resistant subjects (41). The relative importance of this abnormal kinase and PP-1 activities to the reduction of glycogen synthase activity and the pathogenesis of insulin resistance remains unknown. Recent studies $(42,43)$ also show that PP-1 may be involved in the regulation of glucose transport, indicating a multisite action of this enzyme on glucose metabolism. This complexity of actions and regulation makes it difficult to quantitatively predict what decrements of insulin-mediated glucose disposal would result from given decrements of PP-1 activity. This issue is further complicated by the fact that measured PP- 1 activity and stimulation by insulin change with the concentration of the enzyme (unpublished observations). Under the conditions of the present study, however, it is clear that a decrease of PP-1 activity was associated with in vivo insulin resistance in man.

In summary, we show that total PP-1 activity is decreased whereas the level of PP-1 catalytic subunit is increased in subjects with insulin resistance. This reduced PP-1 activity appears to be due to a defect in the catalytic subunit itself and not interaction with heat-stable inhibitors or regulatory proteins.

\section{Acknowledgments}

We wish to thank Carol Lamkin, Aileen Coyne, Darryl Allis, and their nursing staff at the Clinical Diabetes and Nutrition Section, Helen Seagle and the dietary staff, and the technical staff for their professional assistance. Laboratory support by Karen Stone and secretarial help of Charlesetta Lincoln are gratefully acknowledged. Most of all, we thank the Indian volunteers for their cooperation during the studies.

This work was supported in part by grant DK31374 from Public Health Service to Dr. D. L. Brautigan.

\section{References}

1. Bogardus, C., S. Lillioja, K. Stone, and D. Mott. 1984. Correlation between muscle glycogen synthase activity and in vivo insulin action in man. $J$. Clin. Invest. 73:1185-1190.

2. Parker, P. J., F. B. Caudwell, and P. Cohen. 1983. Glycogen synthase from rabbit skeletal muscle: effect of insulin on the state of phosphorylation of seven phosphoserine residues in vivo. Eur. J. Biochem. 130:227-234.

3. Sheorain, V. S., H. Juhl, M. Bass, and T. R. Soderling. 1983. Effects of epinephrine, diabetes, and insulin on rabbit skeletal muscle glycogen synthase. $J$. Biol. Chem. 259:7024-7030.

4. Ballou, L. M., and E. H. Fisher. 1986. Phosphoprotein phosphatases. In The Enzymes. Vol. 17. P. D. Boyer and E. G. Krebs, editors. Academic Press, Inc., Orlando, FL. 311-361.

5. Ingebritsen, T. S., and P. Cohen. 1983. Protein phosphatases: properties and role in cellular regulation. Science (Wash. DC). 221:331-338.

6. Walchenbach, R. J., R. Hazen, and J. Larner. 1978. Reversible inhibition of cyclic AMP-dependent protein kinase by insulin. Mol. Cell. Biochem. 19:31-41.

7. Alemany, S., S. Pelech, C. H. Brierley, and P. Cohen. 1986. The protein phosphatases involved in cellular regulation. Evidence that dephosphorylation of glycogen phosphorylase and glycogen synthase in the glycogen and microsomal fractions of rat livers are catalysed by the same enzyme: protein phosphatase-1. Eur. J. Biochem. 156:101-110.

8. Cohen, P. 1989. The structure and regulation of protein phosphatases. Annu. Rev. Biochem. 58:453-508.

9. Gruppuso, P. A., C. L. Shriner, and D. L. Brautigan. 1987. Latent forms of 
type-1 protein phosphatase in rabbit skeletal muscle. Biochem. Biophys. Res. Commun. 148:1174-1181.

10. Villa-Moruzzi, E., and L. M. G. Heilmeyer. 1987. Phosphorylase phosphatase from skeletal muscle membranes. Eur. J. Biochem. 169:659-667.

11. Freymond, D., C. Bogardus, M. Okubo, K. Stone, and D. M. Mott. 1988. Impaired insulin-stimulated muscle glycogen synthase activities in vivo in man is related to low fasting glycogen synthase phosphatase activity. J. Clin. Invest. 82:1503-1509.

12. Kida, Y., A. Esposito-Del Puente, C. Bogardus, and D. M. Mott. 1990. Insulin resistance is associated with reduced fasting and insulin-stimualted glycogen synthase phosphatase activity in human skeletal muscle. J. Clin. Invest. 85:476-481.

13. Bogardus, C., S. Lillioja, B. V. Howard, G. Reaven, and D. M. Mott. 1985. Relationship between insulin secretion, insulin action, and fasting plasma glucose in non-diabetic and non-insulin dependent diabetic subjects. J. Clin. Invest. 74:1238-1246.

14. Steele, R. 1959. Influences of glucose loading and of injected insulin on hepatic glucose output. Ann. NY Acad. Sci. 82:420-430.

15. Nimmo, H. G., and P. Cohen. 1978. The regulation of glycogen metabolism. Purification and characterization of protein phosphatase inhibitor-1 from rabbit skeletal muscle. Eur. J. Biochem. 87:341-351.

16. Antoniw, J. F., H. G. Nimmo, S. J. Yeaman, and P. Cohen. 1977. Comparison of the substrate specificities of protein phosphatases involved in the regulation of glycogen metabolism in rabbit skeletal muscle. Biochem. J. 162:423-433

17. Villa-Moruzzi, E. 1989. Stimulation of FA and phosphatase-1 activities by insulin in 3T3-L1 cells. FEBS (Fed. Eur. Biochem. Soc.) Lett. 258:208-210.

18. Brautigan, D. L., C. Picton, and E. H. Fischer. 1980. Phosphorylase phosphatase complex from skeletal muscle. Activation of one of two catalytic subunits by manganese ions. Biochemistry. 19:5787-5794.

19. Brautigan, D. L., C. L. Shriner, and P. A. Gruppuso. 1985. Phosphorylase phosphatase catalytic subunit. Evidence that the $\mathrm{Mr}=33,000$ enzyme fragment is derived from a native protein of $\mathrm{Mr}=70,000$. J. Biol. Chem. 260:4295-4302.

20. Brautigan, D. L., P. A. Gruppuso, and M. Mumby. 1986. Protein phosphatase type-1 and type-2 catalytic subunits both bind inhibitor-2 and monoclonal immunoglobulins. J. Biol. Chem. 261:14924-14928.

21. Peng, Z.-Y., W. Wang, S. W. Wilson, K. K. Schlender, R. L. Trumbly, and E. M. Reimann. 1991. Identification of a glycogen synthase phosphatase from yeast Saccharomyces cerevisiae as protein phosphatase 2A. J. Biol. Chem. 266:10925-10932.

22. Herbert, V., K. Lau, C. W. Gottlieb, and S. J. Bleicher. 1965. Coated charcoal immunoassay of insulin. J. Clin. Endocrinol. Metab. 25:1375-1384.

23. Merlevede, W., J. R. Vandenheede, J. Goris, and S. D. Yang. 1984. Regulation of the ATP, Mg-dependent protein phosphatase. Curr. Top. Cell. Regul. 23:177-215.

24. Stralfors, P., A. Hiraga, and P. Cohen. 1985. The protein phosphatases involved in cellular regulation. Purification and characterization of the glycogenbound form of protein phosphatase-1 from rabbit skeletal muscle. Eur. J. Biochem. 149:295-303.

25. Brautigan, D. L., B. S. Khatra, T. R. Soderling, and E. H. Fisher. 1982. Dephosphorylation of skeletal muscle phosphorylase, glycogen synthase, and phosphorylase kinase beta-subunit by a $\mathrm{Mn}^{2+}$-activated protein phosphatase. Arch. Biochem. Biophys. 219:228-235.

26. Foulkes, G. J., and L. S. Jefferson. 1984. Protein phosphatase-1 and $-2 A$ activities in heart, liver and skeletal muscle extracts from control and diabetic rats. Diabetes. 33:576-579.
27. Khandelwal, R. L., S. M. Zinman, and E. J. Zebrowski. 1977. The effect of streptozotocin-induced diabetes and of insulin supplementation on glycogen metabolism in rat liver. Biochem. J. 168:541-548.

28. Miller, T. B., Jr., J. J. Vicalvi, Jr., and A. K. Garnache. 1981. Alteration of hepatic glycogen synthase phosphatase activity by insulin deficiency. Am. J. Physiol. 240:E539-E543.

29. Bollen, M., and W. Stalmans. 1988. The modulator protein dissociates the catalytic subunit of hepatic protein phosphatase $\mathrm{G}$ from glycogen. Biochem. $J$. 250:659-663.

30. Hiraga, A., and P. Cohen. 1986. Phosphorylation of the glycogen-binding subunit of protein phosphatase- $1_{G}$ by cyclic-AMP-dependent protein kinase promotes translocation of the phosphatase from glycogen to cytosol in rabbit skeletal muscle. Eur. J. Biochem. 161:763-769.

31. Dent, P., A. Lavoinne, S. Nakielny, F. B. Caudwell, P. Watt, and P. Cohen. 1990. The molecular mechanism by which insulin stimulates glycogen synthesis in mammalian skeletal muscle. Nature (Lond.). 348:302-308.

32. Silberman, S. R., M. Speth, R. Nemani, M. K. Ganapathi, V. Dombradi, H. Paris, and E. Y. C. Lee. 1984. Isolation and characterization of rabbit skeletal muscle protein phosphatases C-I and C-II. J. Biol. Chem. 259:2913-2922.

33. Tung, H. Y. L., T. J. Resink, B. A. Hemmings, S. Shenolikar, and P. Cohen. 1984. The catalytic subunits of protein phosphatase-1 and protein phosphatase 2 A are distinct gene products. Eur. J. Biochem. 138:635-641.

34. Ingebritsen, T. S., A. A. Stewart, and P. Cohen. 1983. The protein phosphatases involved in cellular regulation. Measurement of type- 1 and type-2 protein phosphatase in extracts of mammalian tissues: an assessment of their physiological roles. Eur. J. Biochem. 132:297-307.

35. Cohen, P. T. W. 1990. Genetics and Human Nutrition. P. J. Randle, editor. Libbey, London. 27-29.

36. Barker, H. M., T. A. Jones, E. F. Da Cruz E. Silva, N. K. Spurr, D. Sheer, and P. T. W. Cohen. 1990. Localization of the gene encoding a type I protein phosphatase catalytic subunit to human chromosome band 11q13. Genomics. 7:149-166.

37. Sasaki, K., H. Shima, Y. Kitagawa, S. Irino, T. Sugimura, and M. Nagao. 1990. Identification of members of the protein phosphatase 1 gene family in the rat and enhanced expression of protein phosphatase $1 \alpha$ gene in rat hepatocellular carcinomas. Jpn. J. Cancer Res. 81:1272-1280.

38. Wadzinski, B. E., L. E. Heasley, and G. L. Johnson. 1990. Multiplicity of protein serine-threonine phosphatases in PC12 pheochromocytoma and FTO-2B hepatoma cells. J. Biol. Chem. 265:21504-21508.

39. Gruppuso, P. A., and D. L. Brautigan. 1989. Induction of hepatic glycogenesis in the fetal rat. Am. J. Physiol. 256:E49-E54.

40. Johansen, J. W., and T. S. Ingebritsen. 1987. Effects of phosphorylation of protein phosphatase I by pp60 $0^{\text {verc }}$ on the interaction of the enzyme with substrates and inhibitor proteins. Biochim. Biophys. Acta. 928:63-75.

41. Kida, Y., B. L. Nyomba, C. Bogardus, and D. M. Mott. 1991. Defective insulin response of cyclic adenosine monophosphate-dependent protein kinase in insulin-resistant humans. J. Clin. Invest. 87:673-679.

42. Corvera, S., S. Jaspers, and M. Pasceri. 1991. Acute inhibition of insulinstimulated glucose transport by the phosphatase inhibitor, okadaic acid. J. Biol. Chem. 266:9271-9275.

43. Tanti, J. F., T. Gremeaux, E. Van Obberghen, and Y. Le Marchand-Brustel. 1991. Effects of okadaic acid, an inhibitor of protein phosphatases-1 and -2A, on glucose transport and metabolism in skeletal muscle. J. Biol. Chem. 266:2099-2103. 